\title{
Influence of Nematicides and Fungicides on Spring Wheat in Fields Infested with Soilborne Pathogens
}

Richard W. Smiley, Jennifer A. Gourlie, and Karl E. L. Rhinhart, Oregon State University, Columbia Basin Agricultural Research Center, Pendleton 97801; Juliet M. Marshall, Cereals Pathology and Agronomy Program, University of Idaho, Idaho Falls 83402; Monte D. Anderson, Bayer CropScience, Spangle, WA 99031; and Guiping Yan, Oregon State University, Columbia Basin Agricultural Research Center

\begin{abstract}
Smiley, R. W., Gourlie, J. A., Rhinhart, K. E. L., Marshall, J. M., Anderson, M. D., and Yan, G. P. 2012. Influence of nematicides and fungicides on spring wheat in fields infested with soilborne pathogens. Plant Dis. 96:1537-1547.

A complex of fungal soilborne pathogens and plant-parasitic nematodes reduces wheat yields in the Pacific Northwest. On several other crops in nematode-infested soils, seed treatment with abamectin (Avicta) or Bacillus firmus (Votivo) or foliar application of spirotetramat (Movento) reduced root injury and improved yield. These products, along with fungicide seed treatments and aldicarb (Temik), were evaluated in 13 spring wheat trials over 3 years. During 2011, the mean wheat yield at four locations was $419 \mathrm{~kg} / \mathrm{ha}$ greater (valued at $\$ 122 / \mathrm{ha}$ ) from seed treated with fungicides and insecticide than from untreated

increased the mean grain yield over the fungicide-plus-insecticide treatment by another $798 \mathrm{~kg} / \mathrm{ha}$ (valued at $\$ 254 / \mathrm{ha}$ ) and also reduced the density of Heterodera avenae but is not registered for use on wheat. Abamectin and B. firmus had negligible effects on grain yield and postharvest density of Pratylenchus spp. and $H$. avenae. Spirotetramat reduced density of $H$. avenae but did not improve grain yield. We conclude that management of fungal pathogens by seed protectants remains essential and that management of nematodes can be achieved through crop rotations and genetic resistance.
\end{abstract} seed, due to protection against soilborne fungal pathogens. Aldicarb
Wheat (Triticum aestivum L.) is planted on 1.7 million hectares annually in the Pacific Northwest (PNW) states of Idaho, Oregon, and Washington (47). In all, $80 \%$ of the wheat is produced under rainfed conditions and $20 \%$ receives supplemental irrigation. Most annual rainfall occurs from late autumn through early spring and the summers are very warm and dry. Mean annual rainfall in the primary wheat-producing areas varies from about 250 to $600 \mathrm{~mm}$. Most wheat fields in the PNW are infested by soilborne plantpathogenic fungi that cause root diseases $(20,32)$. Primary diseases of importance on spring wheat include Fusarium crown rot, takeall, Rhizoctonia root rot, and Pythium damping-off and root rot. Nearly all wheat seed in the PNW is treated with a prophylactic combination of fungicides and often also with an insecticide $(18,20)$. Seed treatments most commonly applied in the region at the current time include the broad-spectrum fungicides difenoconazole or tebuconazole, or a combination of tebuconazole plus imazalil. The broad-spectrum fungicides are always formulated as a mixture with a suppressant of Pythium spp., such as mefenoxam or metalaxyl. Moreover, these fungicide mixtures are often supplemented with an insecticide such as thiamethoxam or imidacloprid to suppress early-season damage from wireworm, Russian wheat aphid, or other pests.

Root-lesion nematodes (Pratylenchus neglectus (Rensch, 1924) Filipjev Schuurmanns \& Stekhoven, 1941 and P. thornei Sher \& Allen, 1953) are also present as individual or mixed populations in a majority of the rainfed fields in low-precipitation regions $(36,44)$. The cereal cyst nematode Heterodera avenae Woll., 1924 is less widespread but occurs in some production districts in at least seven western states of the United States (29). Each of these three plantparasitic nematode species substantially reduces grain yields of

Corresponding author: R. Smiley,

E-mail: richard.smiley@ oregonstate.edu

Accepted for publication 7 May 2012.

http://dx.doi.org/10.1094/PDIS-02-12-0165-RE

(C) 2012 The American Phytopathological Society spring and winter wheat $(31,33,38,39,41)$. Together, these three species reduce the farm-gate revenue for wheat in the PNW by at least $\$ 54$ million annually $(29,31)$.

Practices recommended for managing the impacts of nematodes on wheat are currently limited and are generally economically unrealistic for routine application $(30,42)$. These practices include rotations either to crop species that are not typically produced in the region or to multiple-year periods of bare fallow. Currently, there are no resistant varieties or chemical or biological nematicides available to manage these root parasites. However, newer nematicides had not been evaluated on wheat in the PNW.

Avermectins are a group of macrocyclic lactones produced by Steptomyces avermitilis $(2,28)$. They are used as insecticides and acaricides for crop protection and as anthelminthics in animal health. Abamectin (Avicta 500FS) is a commercial mixture of avermectin $B_{1 a}$ and avermectin $B_{1 b}$ that has been evaluated as a seed treatment to manage the impacts of plant-parasitic nematodes affecting corn (8), cotton (10-12,17,21,23,24), and tobacco (26). Abamectin has also been evaluated in the greenhouse as a protectant for cowpea (7), soybean (27), tomato $(1,3)$, and wheat (19). Results of these tests have generally shown improvements in plant stand establishment but negligible or variable benefits to crop yield and to reducing the nematode density in soil. Mobility of this nematicide is very limited in soil (49) and, in glasshouse tests, most of the treatment effect remained near the treated seed rather than lower on the root system (4). Treatment efficacy increased in response to increasing rates of application to cowpea but higher treatment rates were phytotoxic and the application rate needed to be adjusted to balance effects on plant growth and nematode mortality (7). Root galling and egg production by Meloidogyne incognita were reduced and the foliage weight of tobacco was increased by applications of abamectin in field trials (26). Abamectin was evaluated on wheat for its ability to control $H$. avenae (19). Results from small pot experiments using a sand medium were promising but tests in larger containers filled with an infested field soil were marginal.

Bacillus firmus $\mathrm{I}-1582$ is a biological seed treatment sold in a commercial formulation (Votivo) to protect corn, cotton, and soybean roots against invasion by plant-parasitic nematodes (45). The 
manufacturer states that the bacterium rapidly colonizes the rhizosphere of developing roots and competes with nematodes for root exudates, reducing the attraction of nematodes to the roots. They also state that $B$. firmus does not kill nematodes but acts as a repellent. However, Mendoza et al. (16) reported that B. firmus caused paralysis and mortality of Radopholus similis, M. incognita, and Ditylenchus dipsaci, and reduced hatching of $M$. incognita eggs. Isolates of B. firmus have reduced damage caused by root-knot nematodes $(5,9,16)$. Yield of corn in fields infested with Pratylenchus spp. were slightly improved when seed was treated with $B$. firmus but densities of nematodes in soil and roots were unaffected by the treatment (8).

Spirotetramat (Movento) is a ketoenol insecticide with both phloem and xylem mobility (ambimobile) in many crop species, including wheat $(15,25,46)$. Once inside the leaf, spirotetramat is hydrolyzed to spirotetramat-enol, the form in which the compound enters the xylem and phloem and is translocated throughout the plant. The compound is a group 23 lipid biosynthesis inhibitor that reduces fecundity (number of eggs deposited) and fertility (viability of eggs produced) when ingested orally by immature life stages of sucking insects. Incomplete edysis (shedding of the cuticle during molting) has also been observed in aphid populations, leading to immobility and subsequent death of affected individuals. Spirotetramat is the first broad-spectrum insecticide that exhibits basipetal translocation from foliage into roots. It has very short residual activity in soil, with more than $90 \%$ dissipation in 1 to 4 days, but has a residual activity of two or more weeks within plants. Spirotetramat is registered for controlling many sucking insect pests of horticultural and vegetable crops (Movento label, 30 June 2008; Bayer CropScience). McKenry et al. $(13,14)$ demonstrated that applications to foliage reduced the number of $P$. vulnus in rhizosphere soil around roots of walnut by $50 \%$ over a 6-month period. These authors also found that application of spirotetramat to grape leaves reduced the number of Xiphinema americanum by up to $70 \%$ when roots were sampled 18 days after treatment, reduced the number of Meloidogyne spp. as much as $50 \%$ for up to 3 months, and reduced the number of Tylenchulus semipenetrans for 6 weeks. Smiley et al. (35) reported that a single application of spirotetramat reduced the postharvest density of $H$. avenae by $28 \%$ in an Idaho field and by $78 \%$ in a Washington field but did not improve the yield of spring wheat at either location. In fields infested with low to moderate densities of $P$. thornei, there were no differences among spirotetramat and control treatments for yield or for postharvest nematode density in spring and winter wheat during 2010 (unpublished data).
Abamectin and $B$. firmus do not appear to have been critically evaluated for their capacity to increase grain yields or to suppress the density of nematodes that injure wheat under field conditions. Spirotetramat had not been fully evaluated for controlling damage by root-lesion nematodes. The objectives of this research were to determine the potential for these pesticides alone or in combinations to suppress the density of root-lesion nematode and cereal cyst nematode, and to increase yield of spring wheat. In selected experiments, yields of abamectin treatments were compared with aldicarb treatments that are often used for this research purpose. Other experiments compared yields and profitability of spring wheat produced from seed that was either treated or not treated with prophylactic fungicides and an insecticide.

\section{Materials and Methods}

Formulations of abamectin were applied to spring wheat seed that was planted over a 3-year period (2009 to 2011) into nine fields at five locations (Table 1). Abamectin was compared with aldicarb treatments during 2010 and 2011. Comparisons of untreated seed and seed treated with fungicides plus insecticide were evaluated during 2009 and 2011. During 2011, treatments of $B$. firmus were evaluated in spring wheat trials at four locations, with the $B$. firmus experiments being placed adjacent to trials where abamectin and aldicarb were compared. Overall, five trials were performed near Pendleton, OR during 2009 and 2010, and eight trials were performed at four locations in Idaho, Oregon, and Washington during 2011. Each field was infested with an undetermined species complex of soilborne plant-pathogenic fungi, including species of Pythium, Rhizoctonia, and Fusarium, and one or more of the plant-parasitic nematodes $P$. neglectus, $P$. thornei, $H$. avenae, and Tylenchorhynchus or Merlinius spp. (Table 2).

Field locations. Six experiments were performed near Pendleton, OR, two trials were performed near Cove, OR, and two trials at each location were performed near Mission, OR, Steptoe, WA, and St. Anthony, ID. The Oregon and Washington sites are characterized by Mediterranean, semiarid climates having cool, moist winters and warm, dry summers. The Idaho site had a continental, semiarid climate with cold winters and warm, dry summers. At each location, nearly all precipitation occurs from late autumn (November) through spring (May).

Pendleton, OR. Five experiments during 2009 and 2010 were performed at the Oregon State University Columbia Basin Agricultural Research Center $14 \mathrm{~km}$ northeast of Pendleton, in Umatilla County, at $457 \mathrm{~m}$ of elevation and coordinates of $45.7167 \mathrm{~N}$ and $-118.6169 \mathrm{~W}$. The soil was a variable depth $(90$ to $150 \mathrm{~cm}$ ) Walla Walla silt loam; a coarse-silty, mixed, superactive, mesic Typic

Table 1. Summary of locations and field operations in nine fields where 13 spring wheat experiments were performed to evaluate pesticide treatments in fields naturally infested with soilborne fungal pathogens and one or more of the nematodes Pratylenchus neglectus (Pn), P. thornei (Pt), Heterodera avenae (Ha), and Tylenchorhynchus or Merlinius sp.

\begin{tabular}{|c|c|c|c|c|c|c|c|c|c|c|c|c|}
\hline \multirow[b]{2}{*}{ Year } & \multirow[b]{2}{*}{ Location } & \multirow[b]{2}{*}{ Field } & \multirow[b]{2}{*}{ Nematode $^{u}$} & \multirow[b]{2}{*}{$\begin{array}{c}\text { Soil } \\
\left({ }^{\circ} \mathbf{C}\right)^{v}\end{array}$} & \multicolumn{8}{|c|}{ Date of primary activities ${ }^{t}$} \\
\hline & & & & & Planting & $\begin{array}{l}\text { Stand } \\
\text { rating }\end{array}$ & $\begin{array}{c}\text { Nema } \\
\text { Pi }^{\mathbf{w}}\end{array}$ & $\begin{array}{c}\text { Mov } \\
\text { App. 1x }\end{array}$ & $\begin{array}{c}\text { Mov } \\
\text { App. 2x }\end{array}$ & $\begin{array}{c}\text { Root } \\
\text { samples }^{y}\end{array}$ & Harvest & $\begin{array}{c}\text { Nema } \\
\text { Pf }^{\mathbf{z}}\end{array}$ \\
\hline 2009 & Pendleton, OR & A1 & $\mathrm{Pt}$ & 15 & May 1 & May 12 & Apr 20 & na & na & na & Aug 6 & na \\
\hline 2010 & Pendleton, OR & B1 & $\mathrm{Pt}$ & 8 & Mar 25 & Apr 19 & Apr 7 & na & na & na & Aug 4 & na \\
\hline 2010 & Pendleton, OR & B1 & $\mathrm{Pt}$ & 7 & Apr 14 & May 3 & Apr 7 & na & na & na & Aug 10 & Oct 18 \\
\hline 2010 & Pendleton, OR & A3 & $\mathrm{Pt}$ & 8 & $\operatorname{Mar} 25$ & Apr 19 & Apr 7 & na & na & na & Aug 4 & na \\
\hline 2010 & Pendleton, OR & A3 & $\mathrm{Pt}$ & 7 & Apr 14 & May 3 & Apr 7 & na & na & na & Aug 10 & Oct 18 \\
\hline 2011 & Mission, OR & CT & $\mathrm{Pn}$ & 6 & Apr 6 & May 4 & May 4 & Jun 3 & Jun 16 & na & Aug 18 & Aug 29 \\
\hline 2011 & Cove, OR & SJ & $\mathrm{Pn}, \mathrm{Ha}$ & 9 & May 6 & Jun 3 & May 20 & Jun 16 & Jun 30 & Jul 6 & Sep 21 & Oct 3 \\
\hline 2011 & Steptoe, WA & JS & $\mathrm{Pn}, \mathrm{Ha}$ & 12 & May 11 & Jun 9 & May 11 & Jun 9 & Jun 22 & Aug 8 & Sep 22 & na \\
\hline 2011 & St. Anthony, ID & DD & $\mathrm{Ha}$ & 6 & Apr 28 & Jun 5 & Apr 28 & Jun 5 & Jun 20 & Jun 20 & Sep 21 & Sep 26 \\
\hline
\end{tabular}

${ }^{\mathrm{t}}$ Abbreviations: Apr = April, Aug = August, Jun = June, Mar = March, Oct = October, and Sep = September; na = not applicable.

u Primary nematodes of economic importance at each site.

${ }^{v}$ Soil temperature at seed depth at the time of planting.

${ }^{w}$ Date on which initial nematode density was determined from soil samples collected to 30- to 45-cm depths across the experimental area prior to or immediately following planting.

${ }^{x}$ Dates on which spirotetramat (Movento) was applied to foliage of selected treatments on two occasions during 2011.

y Date on which root samples were collected to evaluate root-knotting symptoms caused by H. avenae.

${ }^{\mathrm{z}}$ Date on which the post-harvest nematode density was determined by collecting 20 soil cores to a 30 -cm depth in each 1.8 -by-9-m plot. 
Haploxeroll (48). Different fields were used for trials each year. Field B1 had a history of being planted annually to spring wheat without tillage. The Adams fields (A1 and A3) were managed as no-till 3-year rotations of winter wheat, spring wheat, and chemical fallow. Both fields were known to be infested by P. thornei $(31,36)$.

Mission, OR. Two experiments during 2011 were located on a field managed by the Confederated Tribes of the Umatilla Indian Reservation, located $10 \mathrm{~km}$ southeast of Pendleton in Umatilla County, at $450 \mathrm{~m}$ of elevation and coordinates $45.6169 \mathrm{~N}$ and -118.6834 W. The soil was a Hermiston silt loam; a deep ( $>200$ $\mathrm{cm})$, coarse-silty, mixed, mesic Cumulic Haploxeroll. The field was maintained as a 3-year rotation including winter wheat during 2008, chemical fallow during 2009, and no-till canola 'DeKalb RR 536' during 2010. The field was selected because it had a high density of $P$. neglectus.

Cove, OR. Two experiments during 2011 were located on a commercial farm located $19 \mathrm{~km}$ east of La Grande in Union County, at $822 \mathrm{~m}$ of elevation and coordinates $45.3002 \mathrm{~N}$ and $-117.8502 \mathrm{~W}$. The soil was a moderately shallow $(90 \mathrm{~cm})$, poorly drained Hot Lake silt loam; a coarse-silty, mixed, mesic, mesic Aquic Haploxeroll. The field was cultivated between crops and was recently planted annually to winter wheat. Our trials followed two successive crops of 'Stephens' and 'ORCF102' winter wheat produced during 2009 and 2010. The site was selected because it had a high density of $P$. neglectus and $H$. avenae.

Steptoe, WA. Two trials during 2011 were located on a farm 15 $\mathrm{km}$ north of Colfax in Whitman County, at $712 \mathrm{~m}$ of elevation and coordinates $47.0002 \mathrm{~N}$ and $-117.3501 \mathrm{~W}$. The soil was a Caldwell silt loam; a very deep ( $>200 \mathrm{~cm}$ ), somewhat poorly drained finesilty, mixed, superactive, mesic Cumulic Haploxeroll. The field was recently planted annually to spring wheat. Our trials followed two consecutive crops of spring wheat 'Buck Pronto' produced during 2009 and 2010. The site was selected because it had a high density of $P$. neglectus and $H$. avenae.

St. Anthony, ID. Two trials during 2011 were located on a farm $16 \mathrm{~km}$ northeast of Rexburg in Fremont County, at 1,509 m of elevation and coordinates $43.9167 \mathrm{~N}$ and $-111.6334 \mathrm{~W}$. The soil was a St. Anthony gravelly sandy loam, a very deep, well-drained loamy-skeletal, mixed, superactive, frigid Calcic Pachic Haploxeroll. The experimental site was a "dry corner" managed as a 2-year rotation of spring wheat and cultivated fallow in a field that is mostly irrigated by a pivot sprinkler system and managed as a 2year rotation of potato and spring wheat. Our trials followed a crop of 'Alturas' spring wheat produced during 2010. The site was selected because it had a high density of $H$. avenae $(35,43)$.

Experimental treatments and design. Each year, six or eight replicates of seed or soil treatments (Table 3) were compared in randomized complete block designs using 1.8-by-9-m plots for each treatment. All seed treatments were applied to a single seed lot each year by either Syngenta Crop Protection at Stanton, MN (applied Dividend Extreme, Cruiser, Rancona, and Avicta) or by
Bayer CropScience at Raleigh, NC (applied Proceed, Poncho, Votivo, and Poncho Votivo). The experiment during 2009 was planted to spring wheat 'Hank' and all trials during 2010 and 2011 were performed with spring wheat 'Alpowa'. A wheat crop preceded each experiment, except during 2011 at Mission, where the experiment followed a canola crop. Nematodes were extracted and quantified from soil samples submitted to Western Laboratories in Parma, ID. Soilborne fungal pathogens in the genera Fusarium, Pythium, and Rhizoctonia in each region have been well documented and are considered ubiquitous $(18,20,32,44)$. These root pathogens were not quantified or identified for experiments reported in this article.

2009 Trial. A single experiment was conducted on a P. thorneiinfested field (A1) at the Columbia Basin Agricultural Research Center near Pendleton. Pre-plant nematode density in the experimental area (0.08 ha) was determined by collecting six soil samples on 20 April 2009. Each sample was a composite of 20 soil cores of $2.5 \mathrm{~cm}$ in diameter by $45 \mathrm{~cm}$ in depth. The previous crop was winter wheat ORCF102 in a 3-year rotation of winter wheat, spring wheat, and chemical fallow. Urea was applied in March as $\mathrm{N}$ at a rate of $90 \mathrm{~kg} / \mathrm{ha}$ and at a $6-\mathrm{cm}$ depth using a double-disk grain drill with openers at $25-\mathrm{cm}$ spacing. Volunteer wheat was killed by application of glyphosate during early April. The trial was planted to hard red spring wheat Hank on 1 May using a John Deere HZ deep-furrow drill equipped with a cone-seeder and four openers at $36-\mathrm{cm}$ spacing. Seed was sown at a density of 237 $\mathrm{seed} / \mathrm{m}^{2}$ into moist soil at a $3-\mathrm{cm}$ depth and seed-zone temperature of $15^{\circ} \mathrm{C}$. Six replicates of three treatments described in Table 3 were tested. Seedling emergence was rated on a 0 -to- 5 scale $(0=$ no stand and $5=$ complete emergence and establishment) 11 days after planting. Broadleaf weeds were controlled by application of herbicides during early June. Grain yield and test weight were calculated after harvesting entire plots using a Hege plot combine (Wintersteiger Inc.).

2010 Trials. Two experiments were conducted on each of two $P$. thornei-infested fields at the Columbia Basin Agricultural Research Center near Pendleton. Field A3 was managed without tillage as a 3-year rotation of winter wheat, spring wheat, and chemical fallow. Spring wheat in this experiment was planted following winter wheat harvested during July 2009. Field B1 was planted annually to spring wheat without tillage. During September 2009 on field B1 and February 2010 on A3, urea was applied at a rate of $\mathrm{N}$ at $56 \mathrm{~kg} / \mathrm{ha}$ and at a $6-\mathrm{cm}$ depth using a double-disk grain drill with openers at $25-\mathrm{cm}$ spacing. The experiment included eight replicates of four treatments (Table 3) planted on two planting dates (Table 1) on both fields: 25 March (early planting) and 14 April (late planting). For both experiments on field B1, volunteer wheat and winter annual weeds were killed by applying glyphosate on 29 August and 2 March and again on 24 March for the 14 April planting date. On field A3, glyphosate was applied on 4 March for both planting dates and again on 31 March for the 14 April plant-

Table 2. Initial density of root-lesion nematode (Pratylenchus neglectus $[\mathrm{Pn}]$ or P. thornei $[\mathrm{Pt}]$ ), cereal cyst nematode (Heterodera avenae $[\mathrm{Ha}]$ ), and stunt nematode (Stunt; Tylenchorhynchus or Merlinius sp.) in seven fields used to evaluate efficacy of nematicide seed treatments on spring wheat over a 3-year period

\begin{tabular}{|c|c|c|c|c|c|c|}
\hline \multirow[b]{2}{*}{ Year } & \multirow[b]{2}{*}{ Location } & \multirow[b]{2}{*}{ Field $^{x}$} & \multirow[b]{2}{*}{ Primary nematode $y$} & \multicolumn{3}{|c|}{ Nematodes/kg of soil } \\
\hline & & & & Pn or Pt & Ha & Stunt $^{\mathrm{z}}$ \\
\hline 2009 & Pendleton, OR & A1 & $\mathrm{Pt}$ & 2,861 & 0 & 1,320 \\
\hline 2010 & Pendleton, OR & B1 & $\mathrm{Pt}$ & 15,180 & 0 & 1,140 \\
\hline 2010 & Pendleton, OR & A3 & Pt & 9,700 & 0 & 528 \\
\hline 2011 & Mission, OR & CTUIR & $\mathrm{Pn}$, few $\mathrm{Pt}$ & 3,300 & 0 & 792 \\
\hline 2011 & Cove, OR & Johnson & Pn, Ha & 13,596 & 2,860 & 429 \\
\hline 2011 & Steptoe, WA & Scholz & $\mathrm{Pn}, \mathrm{Ha}$ & 2,602 & 2,332 & 77 \\
\hline 2011 & St. Anthony, ID & Daw & $\mathrm{Ha}$ & 902 & 6,666 & 66 \\
\hline
\end{tabular}

${ }^{x}$ CTUIR $=$ Confederated Tribes of the Umatilla Indian Reservation.

${ }^{y}$ Primary nematodes of economic importance at each site; P. neglectus $(\mathrm{Pn})$, P. thornei $(\mathrm{Pt})$, or H. avenae (Ha).

${ }^{\mathrm{z}}$ Stunt nematodes were undetermined species of Tylenchorhynchus, Merlinius, or both. Previous experiments have shown that these nematodes are likely to be species of Tylenchorhynchus at each location except Cove, OR and St. Anthony, ID, which are in areas where mixtures of Tylenchorhynchus and Merlinius spp. have been reported. 
ing date. Nematode densities in each field were determined 2 weeks before the earliest planting by collecting two composite samples per field. Each composite consisted of 25 soil cores of 2.5 $\mathrm{cm}$ in diameter by $30 \mathrm{~cm}$ in depth. The four trials were planted to soft white spring wheat Alpowa using the drill, planting density, and planting depth described for the 2009 trial. Seed was dispensed through a cone-seeder and was sown at a 5-cm depth. Aldicarb (Temik 15G) was metered from a Gandy distributor and placed at a $10-\mathrm{cm}$ depth directly below the seed. Separate tubes through the opener maintained separation of seed and nematicide, and the depth of the seed was maintained by a soil packing "wing" located between the seed- and nematicide-tube termini on the drill opener. Seed-zone temperatures were 8 and $7^{\circ} \mathrm{C}$ on 25 March and 14 April, respectively. Stand quality was rated as previously described for seedling emergence on 19 April and 3 May for the first and second plantings, respectively. Broadleaf weeds and stripe rust were controlled by using standard practices for the region. Grain yields and test weights were calculated after harvesting entire plots using a Hege plot combine on 4 August (early planting) or 10 August (late planting). On 18 October, following a rewetting of the soil by rain, postharvest nematode densities were determined in selected treatments of the 14 April planting, using composites of 20 cores collected directly in the wheat row for each 1.8-by-9-m plot.
2011 Trials. Two spring wheat experiments were conducted in each of four commercial fields near Mission, OR, Cove, OR, Steptoe, WA, and St. Anthony, ID. The fields near Mission and Steptoe were planted without tillage and the fields near Cove and St. Anthony were cultivated. One trial at each location (Table 3) evaluated abamectin applied to seed also treated with fungicides and an insecticide, as compared with banding aldicarb into soil planted to seed treated with the basic fungicide and insecticide mixture, and to planting of untreated wheat seed. A second trial at each location (Table 4) evaluated applications of B. firmus applied to seed that was also treated with fungicides and an insecticide, and additions of spirotetramat foliar applications to selected treatments.

Experiments were performed as described during 2010 with the following exceptions. A locally fabricated no-till drill was used to plant these trials. The drill was equipped with two cone-seeders, two Gandy distributors, and four series of row openers spaced at 36 $\mathrm{cm}$. Fluted opening coulters were mounted on a front tool bar and were followed by a sweep-type deep-bander for dispensing fertilizer. A second toolbar was used to mount double-disk openers to dispense seed in line with the opening coulter and deep bander. One Gandy distributor was used to dispense fertilizer $5 \mathrm{~cm}$ below and $4 \mathrm{~cm}$ to each side of the seed row. Seed was dispensed through a cone-seeder and was sown at a 5-cm depth. Aldicarb was delivered from a Gandy box and placed into the seed row with the seed

Table 3. Fungicide, insecticide, and nematicide seed and soil treatments evaluated on spring wheat in the Pacific Northwest from 2009 to $2011^{\mathrm{s}}$

\begin{tabular}{|c|c|c|c|c|c|c|c|c|c|}
\hline \multirow[b]{2}{*}{ Year, Exp, Trt ${ }^{v}$} & \multicolumn{2}{|c|}{ Seed treatments } & \multirow[b]{2}{*}{ Soily } & \multirow[b]{2}{*}{ Grain $(\mathrm{kg} / \mathrm{ha})^{\mathrm{z}}$} & \multicolumn{3}{|c|}{ Nematodes/kg soil ${ }^{t}$} & \multicolumn{2}{|c|}{ Root knot $^{\mathrm{u}}$} \\
\hline & Fungw & Ins or $\operatorname{Nem}^{x}$ & & & Pn or $\mathbf{P t}$ & На & Stunt & Sev (1-5) & Inc $(\%)$ \\
\hline \multicolumn{10}{|l|}{2009} \\
\hline \multicolumn{10}{|l|}{ Pendleton, OR } \\
\hline 1 & None & None & None & 2,168 & nt & nt & nt & nt & nt \\
\hline 2 & Dif + Mef & Thi & None & 2,417 & nt & nt & nt & nt & nt \\
\hline 3 & Dif + Mef & Thi + Aba & None & 2,542 & nt & $\mathrm{nt}$ & $\mathrm{nt}$ & nt & nt \\
\hline $\mathrm{HSD}_{0.05}$ & $\ldots$ & $\ldots$ & $\ldots$ & ns & nt & nt & nt & nt & nt \\
\hline$P>F$ & $\ldots$ & $\ldots$ & $\ldots$ & 0.12 & $\ldots$ & $\ldots$ & $\ldots$ & $\ldots$ & $\ldots$ \\
\hline \multicolumn{10}{|l|}{2010} \\
\hline \multicolumn{10}{|l|}{$\begin{array}{l}\text { Pendleton B1 } \\
25 \text { March }\end{array}$} \\
\hline 1 & Dif + Mef & None & None & $2,927 \mathrm{~b}$ & nt & nt & nt & nt & nt \\
\hline 2 & Dif + Mef & Thi & None & $3,001 \mathrm{~b}$ & nt & nt & nt & nt & $\mathrm{nt}$ \\
\hline 3 & Dif + Mef & Thi + Aba & None & $2,870 \mathrm{~b}$ & nt & $\mathrm{nt}$ & $\mathrm{nt}$ & nt & nt \\
\hline 4 & Dif + Mef & None & Ald & $3,326 \mathrm{a}$ & nt & nt & nt & nt & nt \\
\hline $\mathrm{HSD}_{0.05}$ & $\ldots$ & $\ldots$ & $\ldots$ & 219 & $\ldots$ & $\ldots$ & $\ldots$ & $\ldots$ & $\ldots$ \\
\hline$P>F$ & $\ldots$ & $\ldots$ & $\ldots$ & $<0.01$ & $\ldots$ & $\ldots$ & $\ldots$ & $\ldots$ & $\ldots$ \\
\hline 14 April & & & & & & & & & \\
\hline 1 & Dif + Mef & None & None & $2,778 \mathrm{~b}$ & 3,432 & nt & 99 & nt & nt \\
\hline 2 & Dif + Mef & Thi & None & $2,724 b$ & $\mathrm{nt}$ & $\mathrm{nt}$ & $\mathrm{nt}$ & $\mathrm{nt}$ & nt \\
\hline 3 & Dif + Mef & Thi + Aba & None & $2,724 \mathrm{~b}$ & nt & nt & nt & nt & nt \\
\hline 4 & Dif + Mef & None & Ald & $3,563 \mathrm{a}$ & 2,277 & nt & 33 & nt & $\mathrm{nt}$ \\
\hline $\mathrm{HSD}_{0.05}$ & $\ldots$ & $\ldots$ & $\ldots$ & 284 & ns & $\ldots$ & ns & $\ldots$ & $\ldots$ \\
\hline$P>F$ & $\ldots$ & $\ldots$ & $\ldots$ & $<0.01$ & 0.39 & $\ldots$ & 0.39 & $\ldots$ & $\ldots$ \\
\hline & & & & & & & & ontinued on & ext page) \\
\hline
\end{tabular}

s Abbreviations: $\mathrm{nt}=$ not tested.

${ }^{\mathrm{t}}$ Pratylenchus neglectus $(\mathrm{Pn})$ was present at all locations except Pendleton, where soils are infested by P. thornei $(\mathrm{Pt})$. Ha $=$ Heterodera avenae $($ eggs + juveniles in cysts extracted from soil). Stunt nematodes (Stunt) were undetermined species of Tylenchorhynchus, Merlinius, or both. Previous experience has shown that these nematodes are likely to be species of Tylenchorhynchus at each location except Cove, OR, which is an area where mixtures of Tylenchorhynchus and Merlinius spp. are known to occur.

${ }^{\mathrm{u}}$ Root-knotting symptom caused by $H$. avenae. Severity (Sev) was scaled as $1=$ no evidence of damage, $2=1$ to 3 knots/root system, $3=3$ to 5 knots, $4=$ $>5$ knots and $<20 \%$ reduction in plant height or root mass, and $5=>5$ knots and $>20 \%$ reduction in plant height or root mass. Incidence (Inc) was scaled as percentages of plants that had a minimum of one knotted root.

$v$ Two experiments (Exp) in each of two fields (A3 and B1) at Pendleton, OR during 2010 were adjacent but designed as individual randomized complete blocks planted on 25 March or on 14 April. Trt $=$ treatment.

${ }^{\mathrm{w}}$ Fungicide treatments (Fung) applied to seed: None $=$ no fungicide (bare seed); Dif + Mef $=$ Dividend Extreme $0.96 \mathrm{FS}(0.12 \mathrm{~g}$ of difenoconazole $+0.03 \mathrm{~g}$ of mefenoxam $/ \mathrm{kg}$ of seed) during 2009 and 2010; Dif + Mef + Ipc = Dividend Extreme 0.96FS + Rancona 3.8 FS $(0.18$ g of difenoconazole +0.04 g of mefenoxam $+0.015 \mathrm{~g}$ of ipconazole $/ \mathrm{kg}$ of seed) in 2011 .

${ }^{\mathrm{x}}$ Insecticide (Ins) and nematicide (Nem) treatments applied to seed: None = no insecticide or nematicide; Aba $=$ Avicta $500 \mathrm{FS}$ (0.015 mg of abamectin/seed); Thi $=$ Cruiser 5FS $(0.10 \mathrm{~g}$ of thiamethoxam $/ \mathrm{kg}$ of seed in 2009 and 2010 , and $0.05 \mathrm{~g}$ of thiamethoxam $/ \mathrm{kg}$ of seed in 2011$)$.

y Soil treatment: None $=$ no soil treatment; Ald = Temik $15 \mathrm{G}$ (150 g a.i./kg; $4.2 \mathrm{~kg}$ of aldicarb/ha) was banded $3 \mathrm{~cm}$ below the seed in 2010 or into the seed row in 2011.

${ }^{\mathrm{z}}$ Grain yield. Within individual experiments, the means of grain yield, nematode density, and incidence of root-knot symptoms followed by the same letter within a column did not differ significantly at $\alpha=0.05$ as determined by Tukey's honestly significant difference (HSD) test. Means of severity data for the root-knot symptom were analyzed by the Kruskal-Wallis Test. When the $\chi^{2}$ value for the experiment was significant at $P<0.05$, treatments were examined pairwise to determine which treatments differed significantly; $\mathrm{ns}=$ not significant. 
in selected treatments. Pre-plant weed control using glyphosate was managed by the cooperating farmers.

Fertilizer was applied at the time of planting and was banded by the seed drill at Cove and St. Anthony, where $\mathrm{N}$ at $123 \mathrm{~kg} / \mathrm{ha}$ was applied at a $1: 1$ blend of ammonium phosphate-sulfate $(16 \% \mathrm{~N}$, $\left.20 \% \mathrm{P}_{2} \mathrm{O}_{5}, 15 \% \mathrm{~S}\right)$ and urea $(46 \% \mathrm{~N})$. Wet soils caused the fertilizer shanks to plug at Mission and Steptoe. Therefore, fertilizer was broadcast onto the soil surface immediately prior to planting at Steptoe and 1 week after planting at Mission. Application rates at the latter two locations were $\mathrm{N}$ at 200 and $145 \mathrm{~kg} / \mathrm{ha}$, respectively. The seeding rate at each site was $205 \mathrm{seed} / \mathrm{m}^{2}$. Seed-zone soil temperatures were as described in Table 1. Each experiment included six replicates of each seed, soil, or foliar treatment (Tables 3 and 4). Initial nematode densities were determined on or shortly after planting by collecting composite samples as described in 2010 and on dates described in Table 1. Broadleaf weeds were controlled by the growers or the authors using standard practices for the weed species of importance at each location. Stripe rust was controlled at Steptoe by two foliar applications of fungicide and an infestation of cereal leaf beetle at Cove was controlled by an application of insecticide.

Spirotetramat was applied to foliage of selected treatments on two dates at each location (Tables 1 and 4). The product was tank mixed with a spreading and penetrating adjuvant to maximize leaf uptake and systemicity, as directed on the label (Movento 240FS;
Bayer CropScience). We used a tank mix consisting of $0.25 \%$ ( $\mathrm{vol} / \mathrm{vol}$ ) MSO, a proprietary blend of methylated oils and nonionic surfactants (Helena Chemical Company). Spirotetramat was applied at a rate of $88 \mathrm{~g} / \mathrm{ha}$ with a $\mathrm{CO}_{2}$-pressurized hand-held sprayer with four Tee Jet XR8002 flat fan nozzles spaced at $46-\mathrm{cm}$ intervals and operated at an application volume of 133 liters/ha and a pressure of $207 \mathrm{kPa}$.

Grain yields and test weights were calculated after harvesting entire plots using a Hege plot combine at Cove, Mission, and Steptoe, and a Wintersteiger plot combine (Wintersteiger Inc.) at St. Anthony. Postharvest nematode densities were determined from 20 composited soil cores collected from selected plots using methods described for experiments during 2010.

Economic impact. The economic impact of fungicide and insecticide seed treatments applied to spring wheat seed was estimated by calculating the difference between grain yields in plots planted with treated seed versus untreated seed for the experiment during 2009 and for four 2011 experiments in Table 3. The yield increase (calculated as metric tons per hectare) was multiplied by the mean monthly farm-gate price (dollars per metric ton) received by growers in individual states during the month immediately following the harvest at that location (47). Net profit or loss associated with the yield increase or decrease was calculated using commercial prices for application of the appropriate seed treatments by a commercial seed conditioner during the year in which the treat-

Table 3. (continued from preceding page)

\begin{tabular}{|c|c|c|c|c|c|c|c|c|c|}
\hline \multirow[b]{2}{*}{ Year, Exp, $\operatorname{Trt}^{v}$} & \multicolumn{2}{|c|}{ Seed treatments } & \multirow[b]{2}{*}{ Soily } & \multirow[b]{2}{*}{ Grain $(\mathrm{kg} / \mathrm{ha})^{\mathrm{z}}$} & \multicolumn{3}{|c|}{ Nematodes/kg soil ${ }^{t}$} & \multicolumn{2}{|c|}{ Root knot $^{\mathbf{u}}$} \\
\hline & Fungw & Ins or $\operatorname{Nem}^{x}$ & & & Pn or Pt & Ha & Stunt & $\operatorname{Sev}(1-5)$ & Inc $(\%)$ \\
\hline \multicolumn{10}{|l|}{ Pendleton A3 } \\
\hline \multicolumn{10}{|l|}{25 March } \\
\hline 1 & Dif + Mef & None & None & $4,443 \mathrm{c}$ & nt & nt & $\mathrm{nt}$ & nt & nt \\
\hline 2 & Dif + Mef & Thi & None & $4,651 \mathrm{~b}$ & $\mathrm{nt}$ & nt & $\mathrm{nt}$ & nt & nt \\
\hline 3 & Dif + Mef & Thi + Aba & None & $4,518 \mathrm{bc}$ & nt & nt & nt & nt & $\mathrm{nt}$ \\
\hline 4 & Dif + Mef & None & Ald & $4,916 \mathrm{a}$ & nt & nt & nt & nt & $\mathrm{nt}$ \\
\hline $\mathrm{HSD}_{0.05}$ & $\ldots$ & $\ldots$ & $\ldots$ & 173 & $\ldots$ & $\ldots$ & $\ldots$ & $\ldots$ & $\ldots$ \\
\hline$P>F$ & $\ldots$ & $\ldots$ & $\ldots$ & $<0.01$ & $\ldots$ & $\ldots$ & $\ldots$ & $\ldots$ & $\ldots$ \\
\hline \multicolumn{10}{|l|}{14 April } \\
\hline 1 & Dif + Mef & None & None & $4,635 \mathrm{~b}$ & 3,102 & nt & 66 & nt & nt \\
\hline 2 & Dif + Mef & Thi & None & $4,690 \mathrm{~b}$ & nt & nt & $\mathrm{nt}$ & nt & $\mathrm{nt}$ \\
\hline 3 & Dif + Mef & Thi + Aba & None & $4,688 \mathrm{~b}$ & nt & nt & nt & nt & nt \\
\hline 4 & Dif + Mef & None & Ald & $5,064 \mathrm{a}$ & 1,023 & $\mathrm{nt}$ & 33 & $\mathrm{nt}$ & $\mathrm{nt}$ \\
\hline $\mathrm{HSD}_{0.05}$ & $\ldots$ & $\ldots$ & $\ldots$ & 175 & ns & $\ldots$ & ns & $\ldots$ & $\ldots$ \\
\hline$P>F$ & $\ldots$ & $\ldots$ & $\ldots$ & $<0.01$ & 0.16 & $\ldots$ & 0.39 & $\ldots$ & $\ldots$ \\
\hline \multicolumn{10}{|l|}{2011} \\
\hline \multicolumn{10}{|l|}{ Mission, OR } \\
\hline 1 & None & None & None & $3,391 \mathrm{c}$ & nt & $\mathrm{nt}$ & nt & nt & $\mathrm{nt}$ \\
\hline 2 & Dif + Mef + Ipc & Thi & None & $3,706 \mathrm{bc}$ & 3,372 & 0 & 176 & nt & $\mathrm{nt}$ \\
\hline 3 & Dif + Mef + Ipc & Thi + Aba & None & $4,211 \mathrm{a}$ & 3,793 & 0 & 196 & $\mathrm{nt}$ & nt \\
\hline 4 & Dif + Mef + Ipc & Thi & Ald & $3,958 \mathrm{ab}$ & 3,678 & 0 & 0 & nt & $\mathrm{nt}$ \\
\hline $\mathrm{HSD}_{0.05}$ & $\ldots$ & $\ldots$ & $\ldots$ & 538 & ns & $\ldots$ & ns & $\ldots$ & $\ldots$ \\
\hline$P>F$ & $\ldots$ & $\ldots$ & $\ldots$ & 0.04 & 0.95 & $\ldots$ & 0.09 & $\ldots$ & $\ldots$ \\
\hline \multicolumn{10}{|l|}{ Steptoe, WA } \\
\hline 1 & None & None & None & 3,184 & $\mathrm{nt}$ & nt & $\mathrm{nt}$ & $4.6 \mathrm{a}$ & 100 \\
\hline 2 & Dif + Mef + Ipc & Thi & None & 3,657 & $\mathrm{nt}$ & nt & nt & $4.6 \mathrm{a}$ & 100 \\
\hline 3 & Dif + Mef + Ipc & Thi + Aba & None & 3,743 & nt & nt & nt & $4.9 \mathrm{a}$ & 100 \\
\hline 4 & $\operatorname{Dif}+\mathrm{Mef}+\mathrm{Ipc}$ & Thi & Ald & 3,614 & nt & nt & $\mathrm{nt}$ & $4.1 \mathrm{~b}$ & 100 \\
\hline $\mathrm{HSD}_{0.05}$ & $\ldots$ & $\ldots$ & $\ldots$ & ns & $\ldots$ & $\ldots$ & $\ldots$ & $\ldots$ & $\ldots$ \\
\hline$P>F$ & $\ldots$ & $\ldots$ & $\ldots$ & 0.71 & $\ldots$ & $\ldots$ & $\ldots$ & $<0.01$ & $\ldots$ \\
\hline \multicolumn{10}{|l|}{ Cove, OR } \\
\hline 1 & None & & None & $1,628 \mathrm{~b}$ & nt & nt & $\mathrm{nt}$ & $3.8 \mathrm{a}$ & $100 \mathrm{a}$ \\
\hline 2 & $\mathrm{Dif}+\mathrm{Mef}+\mathrm{Ipc}$ & Thi & None & $2,251 \mathrm{~b}$ & $39,248 \mathrm{a}$ & $12,584 \mathrm{a}$ & 0 & $3.9 \mathrm{a}$ & $98 \mathrm{a}$ \\
\hline 3 & Dif + Mef + Ipc & Thi + Aba & None & $1,965 \mathrm{~b}$ & $27,016 \mathrm{ab}$ & $13,992 \mathrm{a}$ & 0 & $3.6 \mathrm{a}$ & 99 a \\
\hline 4 & Dif + Mef + Ipc & Thi & Ald & $4,704 \mathrm{a}$ & $2,024 \mathrm{~b}$ & $877 \mathrm{~b}$ & 117 & $2.0 \mathrm{~b}$ & $88 \mathrm{~b}$ \\
\hline $\mathrm{HSD}_{0.05}$ & $\ldots$ & $\ldots$ & $\ldots$ & 898 & 22,035 & 9,820 & ns & $\ldots$ & 10 \\
\hline$P>F$ & $\ldots$ & $\ldots$ & $\ldots$ & $<0.01$ & 0.05 & 0.05 & 0.22 & $<0.01$ & 0.05 \\
\hline \multicolumn{10}{|l|}{ St. Anthony, ID } \\
\hline 1 & None & & None & $2,139 \mathrm{~b}$ & $\mathrm{nt}$ & nt & nt & 4.8 & 100 \\
\hline 2 & Dif + Mef + Ipc & Thi & None & $2,403 \mathrm{~b}$ & 2,259 & 35,200 & 249 & 4.9 & 100 \\
\hline 3 & Dif + Mef + Ipc & Thi + Aba & None & $2,441 \mathrm{ab}$ & 4,048 & 34,496 & 1,114 & 4.8 & 100 \\
\hline 4 & Dif + Mef + Ipc & Thi & Ald & $2,931 \mathrm{a}$ & 3,212 & 21,824 & 88 & 4.6 & 100 \\
\hline $\mathrm{HSD}_{0.05}$ & $\ldots$ & $\ldots$ & $\ldots$ & 497 & ns & ns & ns & ns & $\ldots$ \\
\hline$P>F$ & $\ldots$ & $\ldots$ & $\ldots$ & 0.05 & 0.85 & 0.76 & 0.18 & 0.75 & $\ldots$ \\
\hline
\end{tabular}


Table 4. Insecticide and nematicide treatments evaluated on spring wheat in combination with the fungicide seed treatment Proceed Concentrate $123 \mathrm{FS}$ in the Pacific Northwest during $2011^{\mathrm{t}}$

\begin{tabular}{|c|c|c|c|c|c|c|c|c|}
\hline \multirow[b]{2}{*}{ Exp, Trt $^{w}$} & \multicolumn{2}{|c|}{ Treatment } & \multirow[b]{2}{*}{ Grain $(\mathrm{kg} / \mathrm{ha})^{\mathrm{z}}$} & \multicolumn{3}{|c|}{ Nematodes/kg soilu } & \multicolumn{2}{|c|}{$\operatorname{Root}_{\text {knot }^{v}}$} \\
\hline & Seed $^{x}$ & Foliar $^{\mathrm{y}}$ & & Pn & Ha & Stunt & Severity (1-5) & Incidence (\%) \\
\hline \multicolumn{9}{|c|}{ Mission, OR } \\
\hline 1 & None & None & $3,940 \mathrm{ab}$ & 1,364 & nt & 132 & nt & nt \\
\hline 2 & Clo & None & $4,153 \mathrm{ab}$ & 1,833 & nt & 293 & $\mathrm{nt}$ & $\mathrm{nt}$ \\
\hline 3 & Clo + Bfirmus & None & $4,164 \mathrm{ab}$ & nt & nt & nt & nt & nt \\
\hline 4 & Clo + Bfirmus & None & $4,721 \mathrm{a}$ & nt & $\mathrm{nt}$ & $\mathrm{nt}$ & nt & nt \\
\hline 5 & Clo + Bfirmus & None & $4,168 \mathrm{ab}$ & nt & $\mathrm{nt}$ & $\mathrm{nt}$ & nt & $\mathrm{nt}$ \\
\hline 6 & Clo + Bfirmus & None & $4,423 \mathrm{a}$ & 1,452 & nt & 88 & nt & nt \\
\hline 7 & Clo & Spir & $3,530 \mathrm{~b}$ & 1,291 & $\mathrm{nt}$ & 88 & nt & nt \\
\hline 8 & Clo + Bfirmus & Spir & $4,061 \mathrm{ab}$ & nt & $\mathrm{nt}$ & nt & nt & nt \\
\hline 9 & Clo + Bfirmus & Spir & $4,000 \mathrm{ab}$ & 3,256 & nt & 191 & nt & nt \\
\hline $\mathrm{HSD}_{0.05}$ & $\ldots$ & $\ldots$ & 528 & ns & $\ldots$ & ns & $\ldots$ & $\ldots$ \\
\hline$P>F$ & $\ldots$ & $\ldots$ & 0.01 & 0.65 & $\ldots$ & 0.79 & $\ldots$ & $\ldots$ \\
\hline \multicolumn{9}{|c|}{ Steptoe, WA } \\
\hline 1 & None & None & 2,449 & nt & nt & nt & 5.0 & 100 \\
\hline 2 & Clo & None & 2,886 & nt & $\mathrm{nt}$ & $\mathrm{nt}$ & 5.0 & 100 \\
\hline 3 & Clo + Bfirmus & None & 2,411 & $\mathrm{nt}$ & nt & nt & 5.0 & 100 \\
\hline 4 & Clo + Bfirmus & None & 2,459 & $\mathrm{nt}$ & nt & $\mathrm{nt}$ & 5.0 & 100 \\
\hline 5 & Clo + Bfirmus & None & 2,678 & $\mathrm{nt}$ & nt & nt & 5.0 & 100 \\
\hline 6 & Clo + Bfirmus & None & 2,758 & nt & $\mathrm{nt}$ & nt & 5.0 & 100 \\
\hline 7 & Clo & Spir & 3,203 & nt & nt & nt & 5.0 & 100 \\
\hline 8 & Clo + Bfirmus & Spir & 3,063 & nt & nt & nt & 5.0 & 100 \\
\hline 9 & Clo + Bfirmus & Spir & 3,209 & nt & $\mathrm{nt}$ & $\mathrm{nt}$ & 5.0 & 100 \\
\hline $\mathrm{HSD}_{0.05}$ & $\ldots$ & $\ldots$ & ns & $\ldots$ & $\ldots$ & $\ldots$ & ns & ns \\
\hline$P>F$ & $\ldots$ & $\ldots$ & 0.91 & $\ldots$ & $\ldots$ & $\ldots$ & $\ldots$ & $\ldots$ \\
\hline \multicolumn{9}{|l|}{ Cove, OR } \\
\hline 1 & None & None & 3,150 & 18,656 & 49,456 & 968 & 4.7 & 100 \\
\hline 2 & Clo & None & 3,753 & 19,888 & 29,128 & 176 & 4.7 & 100 \\
\hline 3 & Clo + Bfirmus & None & 3,231 & $\mathrm{nt}$ & $\mathrm{nt}$ & nt & 4.6 & 100 \\
\hline 4 & Clo + Bfirmus & None & 3,309 & nt & nt & nt & 4.7 & 100 \\
\hline 5 & Clo + Bfirmus & None & 3,381 & $\mathrm{nt}$ & $\mathrm{nt}$ & nt & 4.7 & 100 \\
\hline 6 & Clo + Bfirmus & None & 3,499 & 16,632 & 20,240 & 528 & 4.6 & 100 \\
\hline 7 & Clo & Spir & 2,970 & 21,736 & 24,552 & 235 & 4.8 & 100 \\
\hline 8 & Clo + Bfirmus & Spir & 2,998 & $\mathrm{nt}$ & nt & nt & 4.7 & 100 \\
\hline 9 & Clo + Bfirmus & Spir & 3,431 & 21,472 & 32,296 & 455 & 4.7 & 100 \\
\hline $\mathrm{HSD}_{0.05}$ & $\ldots$ & $\ldots$ & ns & ns & ns & ns & ns & ns \\
\hline$P>F$ & $\ldots$ & $\ldots$ & 0.55 & 0.48 & 0.78 & 0.28 & 0.18 & $\ldots$ \\
\hline \multicolumn{9}{|c|}{ St. Anthony, ID } \\
\hline 1 & None & None & 2,421 & 2,548 & 45,408 & 396 & 4.4 & 100 \\
\hline 2 & Clo & None & 2,399 & 1,408 & 10,648 & 191 & 4.6 & 100 \\
\hline 3 & Clo + Bfirmus & None & 2,691 & $\mathrm{nt}$ & $\mathrm{nt}$ & nt & 4.3 & 100 \\
\hline 4 & Clo + Bfirmus & None & 2,458 & $\mathrm{nt}$ & nt & $\mathrm{nt}$ & 4.6 & 100 \\
\hline 5 & Clo + Bfirmus & None & 1,901 & nt & $\mathrm{nt}$ & nt & 4.2 & 100 \\
\hline 6 & Clo + Bfirmus & None & 2,943 & 3,784 & 37,576 & 197 & 4.8 & 100 \\
\hline 7 & Clo & Spir & 2,200 & 1,584 & 12,980 & 73 & 4.4 & 100 \\
\hline 8 & Clo + Bfirmus & Spir & 2,355 & nt & nt & nt & 4.4 & 100 \\
\hline 9 & Clo + Bfirmus & Spir & 2,479 & 2,552 & 18,143 & 220 & 4.1 & 100 \\
\hline $\mathrm{HSD}_{0.05}$ & $\ldots$ & $\ldots$ & ns & $\mathrm{ns}$ & $\mathrm{ns}$ & $\mathrm{ns}$ & ns & ns \\
\hline$P>F$ & $\ldots$ & $\ldots$ & 0.35 & 0.20 & 0.17 & 0.74 & 0.98 & $\ldots$ \\
\hline
\end{tabular}

t Abbreviations: $\mathrm{nt}=$ not treated and $\mathrm{ns}=$ not significant.

${ }^{\text {u }} \mathrm{Pn}=$ Pratylenchus neglectus. $\mathrm{Ha}=$ Heterodera avenae (eggs + juveniles in cysts extracted from soil). Stunt nematodes (Stunt) were undetermined species of Tylenchorhynchus, Merlinius, or both. Previous experience has shown that these nematodes are likely to be species of Tylenchorhynchus at each location except Cove, OR, which is an area where mixtures of Tylenchorhynchus and Merlinius sp. are known to occur.

${ }^{\mathrm{v}}$ Root-knotting symptoms caused by $H$. avenae. Severity was scaled as $1=$ no evidence of damage, $2=1$ to $3 \mathrm{knots} /$ root system, $3=3$ to 5 knots, $4=>5$ knots and $<20 \%$ reduction in plant height or root mass, and $5=>5$ knots and $>20 \%$ reduction in plant height or root mass. Incidence was scaled as percentages of plants that had a minimum of one knotted root.

${ }^{w}$ Experiment and treatments.

${ }^{x}$ Seed in all treatments were treated with the fungicide mixture Proceed Concentrate $123 \mathrm{FS}(0.05 \mathrm{~g}$ of prothioconazole $+0.01 \mathrm{~g}$ of tebuconazole $+0.02 \mathrm{~g}$ of prothioconazole $/ \mathrm{kg}$ of seed). Additional insecticide and nematicide treatments applied to seed: None = no insecticide or nematicide; Clo $=$ Poncho $600 \mathrm{FS}$ $(0.31 \mathrm{~g}$ of clothianidin $/ \mathrm{kg}$ of seed in all treatments except number 3$)$; Clo + Bfirmus $=$ Poncho Votivo $600 \mathrm{FS}$ in treatment number 3 (0.76 $\mathrm{g}$ of clothianidin $/ \mathrm{kg}$ of seed; clothianidin at $500 \mathrm{~g} / \mathrm{liter}+$ Bacillus firmus I-1582 at $\left.100 \mathrm{~g} / \mathrm{liter} ;>2 \times 10^{9} \mathrm{CFU} / \mathrm{seed}\right)$ and Poncho $600 \mathrm{FS}+\mathrm{Votivo} 240 \mathrm{FS}$ (B. firmus I-1582 at $240 \mathrm{~g} /$ liter $)$ in treatments $4-6,8$, and $9\left(1 \times 10^{5} \mathrm{CFU} /\right.$ seed in treatments 4 and $8,1 \times 10^{6} \mathrm{CFU} / \mathrm{seed}$ in treatment 5 , and $1 \times 10^{7} \mathrm{CFU} / \mathrm{seed}$ in treatments 6 and 9).

${ }^{\mathrm{y}}$ Foliar treatment: None $=$ no foliar treatment; Spir $=$ Movento 240FS (spirotetramat at $88 \mathrm{~g} / \mathrm{ha}$ ) was applied as a foliar spray. The product was applied as a tank mix consisting of $0.25 \%$ ( vol/vol) MSO, a proprietary blend of methylated oils and non-ionic surfactants (Helena Chemical Company). The spray mixture was applied with a $\mathrm{CO}_{2}$-pressurized hand-held sprayer with four Tee Jet XR8002 flat fan nozzles spaced at 46-cm intervals and operated at an application volume of 133 liters/ha and a pressure of $207 \mathrm{kPa}$.

${ }^{\mathrm{z}}$ Grain yield. Within individual experiments, the means of grain yield, nematode density, and incidence of root-knot symptoms followed by the same letter within a column did not differ significantly at $\alpha=0.05$ as determined by Tukey's honestly significant difference (HSD) test. Means of severity data for the root-knot symptom were analyzed by the Kruskal-Wallis Test. When the $\chi^{2}$ value for the experiment was significant at $P<0.05$, treatments were examined pairwise to determine which treatments differed significantly. 
ment was applied (Mid-Columbia Producers, personal communication). Differences in yield associated with the addition of non-commercially available seed treatments such as abamectin or soil treatments such as aldicarb were calculated similarly but it was only possible to calculate gross revenues for grain harvested because treatment expenses were not available for calculating net profit or loss associated with yield increase or decrease associated with the non-commercial treatments.

Nematode density and identification. Composite samples were collected as previously described and were submitted to Western Laboratories at Parma, ID for extraction and enumeration of all plant-parasitic nematode genera. The laboratory uses a modified Oosterbrink elutriator method described previously (35). Briefly, vermiform and encysted life stages were extracted and collected on separate sieves. Cysts of $H$. avenae were broken mechanically to extract eggs and larvae and the suspension was added to the suspension of vermiform life stages of all species present in the soil. The suspension was then concentrated through multiple sequences of centrifugation and density flotation using a magnesium sulfate solution. All plant-parasitic nematodes were enumerated and reported at the genus level. Nematode density data from replicated plots were normalized using the $\ln +1$ transformation before analysis of variance (ANOVA; 22). Densities reported in the tables are back-transformations to real numbers from the logarithmically transformed numbers used for analyses.

Heterodera and Pratylenchus spp. extracted from samples at each location were identified during previous research and during surveys of the experimental areas $(35,36,38,39,41,43,50,51)$. Each species of these genera was identified using combinations of morphological and molecular methods $(50,52)$. Stunt nematode genera detected in this study were not identified to species. Previous experience and surveys have shown that these nematodes were likely to be species of Tylenchorhynchus (mostly T. clarus) at all experimental sites except Cove, OR and St. Anthony, ID, which are in regions where a mixture of T. clarus and Merlinius brevidens (= Geocenamus brevidens) have been documented $(6,36,40)$.

Root knotting caused by $\boldsymbol{H}$. avenae. Plants were removed from each of the spring wheat plots at Cove, Steptoe, and St. Anthony during 2011 to examine the severity and incidence of the root-knotting symptom caused by $H$. avenae. Twenty plants were rated visually for severity (1-to-5 scale) and incidence (percentage of symptomatic plants). Severity was scaled as follows: $1=$ no evidence of damage, $2=1$ to 3 knots/root system, $3=3$ to 5 knots, $4=>5$ knots and $<20 \%$ reduction in plant height or root mass, and $5=>5$ knots and $>20 \%$ reduction in plant height or root mass.
Weather data. Precipitation data for each location were taken from the parameter-elevation regressions on independent slopes model (PRISM) available from the PRISM Climate Group at Oregon State University. The model presents spatial climate data based upon an expert systems approach utilizing point measurements of precipitation, temperature, and other climatic and geographic factors to produce continuous digital grid estimates of climatic parameters. Precipitation estimates for each research site was accessed via the website http://www.prism.oregonstate.edu, selecting the "explore our data sets" link, and inserting the longitude and latitude coordinates for an experimental site.

Statistical analysis. Within individual experiments, the means for grain yield, nematode density, and incidence of the root knot symptom were analyzed individually using univariate ANOVA with chemical treatments as the treatment variable and replicates as blocks. ANOVA was performed using CoStat Statistical Software version (Co-Stat v. 6.400; CoHort Software). When treatment means were significant at $P<0.05$, means were separated using the Tukey's honestly significant difference (HSD) test. Analyses were performed on nematode density data normalized by using the $\ln (x+1)$ transformation. Means of ordinate data for ratings of stand density and root knot severity were analyzed by the KruskalWallis Test. When the $\chi^{2}$ value for the experiment was significant at $P<0.05$, treatments were examined pairwise to determine which treatments differed significantly.

\section{Results}

2009 Trial. Precipitation $(389 \mathrm{~mm}$ ) for the crop year (1 September to 31 August) was $12 \%$ less than the 30 -year mean $(442 \mathrm{~mm})$ for the Pendleton, OR site. P. thornei was the only plant-parasitic nematode of potential economic importance at the experimental site (Table 2). Plant emergence was excellent and did not differ among treatments (data not shown). Although we did not detect any important diseases or insects that would have affected the integrity of roots, crowns, or foliage, a low incidence and severity of Rhizoctonia root rot occurred in the untreated control (data not shown).

Grain yield did not differ significantly $(P=0.12)$ between crops produced from untreated seed or seed treated with difenoconazole + mefenoxam + thiamethoxam (Dividend Extreme + Cruiser); 2,168 versus $2,417 \mathrm{~kg} / \mathrm{ha}$, respectively (Table 3 ). Nevertheless, the mean numerical increase in grain yield $(249 \mathrm{~kg} / \mathrm{ha})$ from the fungicide-plus-insecticide treatment was valued at an additional gross income of $\$ 46.54 /$ ha but a net reduction of income $(\$-14.49)$ due to the high cost of the insecticide seed treatment during 2009 (Table 5). Grain yield for the treatment containing abamectin in addi-

Table 5. Influence of fungicide and insecticide seed treatments on grain yield and grain value compared with planting seed without any prophylactic treatment ${ }^{\mathrm{v}}$

\begin{tabular}{|c|c|c|c|c|c|c|}
\hline \multirow[b]{2}{*}{ Year } & \multirow[b]{2}{*}{ Field, location } & \multicolumn{2}{|c|}{ Yield (kg/ha) ${ }^{\mathrm{w}}$} & \multirow[b]{2}{*}{ Difference $^{x}$} & \multicolumn{2}{|c|}{ Profit (\$/ha) } \\
\hline & & Untreated seed & Treated seed & & Gross $^{y}$ & $\operatorname{Net}^{\mathrm{z}}$ \\
\hline 2009 & Pendleton, OR & $2,168 \pm 92 \mathrm{a}$ & $2,417 \pm 105 \mathrm{a}$ & 249 & 46.54 & -14.49 \\
\hline 2011 & Mission, OR & $3,391 \pm 196 \mathrm{a}$ & $3,706 \pm 200 \mathrm{a}$ & 315 & 103.41 & 91.68 \\
\hline 2011 & Steptoe, WA & $3,183 \pm 472 \mathrm{a}$ & $3,657 \pm 533 \mathrm{a}$ & 473 & 155.28 & 143.55 \\
\hline 2011 & Cove, OR & $1,628 \pm 389 a$ & $2,251 \pm 478 \mathrm{a}$ & 623 & 204.52 & 192.79 \\
\hline 2011 & St. Anthony, ID & $2,139 \pm 873 \mathrm{a}$ & $2,403 \pm 481 \mathrm{a}$ & 264 & 72.03 & 60.30 \\
\hline 2011 & Four-location mean & $2,585 \pm 231 \mathrm{a}$ & $3,037 \pm 188 \mathrm{~b}$ & 419 & 133.81 & 122.08 \\
\hline
\end{tabular}

${ }^{\mathrm{v}}$ Treatments compared with the untreated-seed control during 2009 were difenoconazole + mefenoxam + thiamethoxam (Dividend Extreme + Cruiser) and during 2011 were difenoconazole + mefenoxam + ipconazole + thiamethoxam (Dividend Extreme + Rancona + Cruiser).

${ }^{w}$ Mean \pm standard error of the mean. Comparative yield data followed by the same letter within a row did not differ significantly at $\alpha=0.05$ as determined by Tukey's honestly significant difference test.

${ }^{x}$ Yield increase from plots planted with treated seed compared with untreated (bare) seed.

${ }^{y}$ Farm-gate value of the additional production reflects the mean monthly farm-gate value for soft-white spring wheat in each state during the month immediately following that in which these crops were harvested; $\$ 186.91$ and $\$ 328.29 /$ metric ton in Oregon during 2009 and 2011, respectively; and $\$ 272.84$ and \$328.29/metric ton in Idaho and Washington, respectively, during 2011.

${ }^{z}$ Net profit is the value of increased grain production minus the expense for the seed treatment applied, using historical cost figures for the year in which the treatment would have been applied. The cost for growers to purchase the specified seed treatments from a commercial seed conditioner during 2009 would have been $\$ 0.45 / \mathrm{kg}$ (equivalent to $\$ 61.03 / \mathrm{ha}$ for seed planted at $135 \mathrm{~kg} / \mathrm{ha}$ ) and, during 2011 , would have been $\$ 0.09 / \mathrm{kg}$ (equivalent to $\$ 11.73 / \mathrm{ha}$ ). During 2009 , the additive expenses for individual treatments were $\$ 0.07 / \mathrm{kg}$ for difenoconazole + mefenoxam (Dividend Extreme) and $\$ 0.38 / \mathrm{kg}$ for thiamethoxam (Cruiser). The combination treatment during 2011 was priced as a package. 
tion to the basic fungicide-plus-insecticide treatment $(2,542 \mathrm{~kg} / \mathrm{ha})$ was greater than for untreated seed but was statistically $(P=0.12)$ equal to seed treated with the basic treatment (Table 3 ). The gross value of additional grain produced from seed treated with abamectin would have been $\$ 23.36 /$ ha (Table 6). Grain test weights did not differ among treatments; 709 to $716 \mathrm{~kg} / \mathrm{m}^{3}, P=0.98$.

2010 Trials. Precipitation $(441 \mathrm{~mm})$ for the crop year was similar to the 30-year mean of $442 \mathrm{~mm}$ for the Pendleton, OR site. P. thornei was the only plant-parasitic nematode species of economic importance at the trial sites (Table 2). Seedling emergence did not differ significantly among treatments in either planting made on 14 April (data not shown). Emergence ratings differed in the 25 March planting in field A3, where the thiamethoxam treatment rating of 3.5 was less than for the other three treatments, which had ratings of 4.3 to 4.6 ( $P=0.02$, according to the Kruskal-Wallis Test).

Grain yields differed among treatments in all four trials (Table 3 ). The aldicarb treatment produced greater grain yield than other treatments in both fields for both planting dates. The value of grain produced from seed treated with aldicarb was greater than from seed with the basic fungicide treatment at each location and planting date, with a four-field mean positive additional gross income from grain sales valued at $\$ 102.26 /$ ha (Table 6). In comparison, treatments with thiamethoxam or thiamethoxam + abamectin were variably positive or negative, compared with the fungicide base treatment, depending upon field and planting date. The mean additional value of grain produced in the thiamethoxam and thiamethoxam + abamectin treatments was far less than from wheat produced in the aldicarb-treated soil (Table 6).

Grain test weight was increased in the aldicarb treatment by 20 $\mathrm{kg} / \mathrm{m}^{3}$ compared with the fungicide-only control $\left(\mathrm{HSD}_{0.05}=13\right)$ in the late-planted experiment in the A3 field (data not presented). Test weights did not differ significantly among treatments in field B1 and in the early-planted experiment in the A3 field. However, in the latter field, test weights were numerically greater in the aldicarb and abamectin treatments compared with the fungicide-only control; 730,734 , and $709 \mathrm{~kg} / \mathrm{m}^{3}$, respectively $(P=0.06)$.

Where postharvest sampling was performed, the density of $P$. thornei and of stunt nematodes did not differ among the fungicideonly treatment and the fungicide + thiamethoxam + abamectin treatment (Table 3).

2011 Dividend Rancona trials. Syngenta Crop Protection products and aldicarb were evaluated at one location (Mission) infested primarily by $P$. neglectus, at two sites (Cove and Steptoe) infested by economically important densities of both $P$. neglectus and $H$. avenae, and at one site (St. Anthony) infested primarily by $H$. avenae (Table 2).
Precipitation during the 2010-11crop year was greater than the 30 -year historical means at all locations. Precipitation at Mission (559 $\mathrm{mm})$, Cove $(555 \mathrm{~mm})$, Steptoe $(598 \mathrm{~mm})$, and St. Anthony $(419 \mathrm{~mm})$ was $37,22,14$, or $19 \%$ greater than the long-term means of $407,454,526$, and $351 \mathrm{~mm}$, respectively.

Stand density at Mission was improved by treating with abamectin or aldicarb compared with the basic control treatment of fungicides plus insecticide (propiconazole + mefenoxam + ipconazole + thiamethoxam; Dividend + Rancona + Cruiser $)$; ratings of $8.3,8.8$, and 7.2, respectively ( $P=0.0078$ according to the Kruskall-Wallis Test). Stand establishment did not differ significantly among treatments at Cove, Steptoe, and St. Anthony (data not shown). At all locations, the establishment of the seedling stand was similar in plots planted with untreated seed compared with plots planted with propiconazole + mefenoxam + ipconazole + thiamethoxam. However, at Mission, wheat in two plots died after becoming established due to damping-off caused by an undetermined species of Pythium; both plots had received the aldicarb treatment in soil overlain by partially decomposed wind rows of canola stubble remaining from the previous crop. Stand density remained excellent in all other plots at Mission, including other plots planted through old canola wind rows.

Root-knotting severity, caused by $H$. avenae, did not differ among treatments at St. Anthony but was less in the aldicarb treatment than in other treatments at Cove and Steptoe (Table 3). The incidence of root knotting was very high at each of these three locations and was moderated by aldicarb at only one location (Cove) and not by abamectin at any of the sites.

Compared with the untreated seed controls, grain yield was numerically greater in the basic treatment of fungicides plus insecticide at each of the four sites (range of 9.3 to $38.3 \%$; mean $=$ $18.7 \%$ ) but the difference due to treating the seed with this basic treatment was not statistically significant at any site (Table 5). Nevertheless, the mean numerical increase in grain yield from treating seed with the mixture of propiconazole + mefenoxam + ipconazole + thiamethoxam during 2011 varied from 264 to 623 $\mathrm{kg} / \mathrm{ha}$ and was valued at an additional gross income of $\$ 72.03$ to $\$ 204.52 /$ ha and a net profit of $\$ 60.30$ to $\$ 192.79$ (Table 5). When averaged over the four locations, the mean increase in grain production $(419 \mathrm{~kg} / \mathrm{ha} ; P=0.04)$ was valued at $\$ 133.81 / \mathrm{ha}$ and the average net profit was valued at $\$ 122.08 /$ ha. Compared with the base treatment, addition of aldicarb improved grain yield at Cove and St. Anthony and abamectin improved yield at Mission. The response from aldicarb was especially striking at Cove, where grain yields were more than doubled in the aldicarb treatment compared with all other treatments (Table 3 ). The four-location mean

Table 6. Influence of abamectin and aldicarb nematicidal treatments on grain yield and value compared with planting seed receiving basic fungicide and insecticide seed treatments

\begin{tabular}{|c|c|c|c|c|c|c|c|}
\hline \multirow[b]{2}{*}{ Year } & \multirow[b]{2}{*}{ Location } & \multicolumn{2}{|c|}{ Treatment comparison } & \multicolumn{3}{|c|}{ Yield $(\mathrm{kg} / \mathrm{ha})^{\mathrm{u}}$} & \multirow[b]{2}{*}{ Profit $(\$ / \mathbf{h a})^{x}$} \\
\hline & & Base $^{\mathbf{v}}$ & Additional & Base & Additional & Difference $^{w}$ & \\
\hline 2009 & Pendleton, OR & DMT & Abamectin & $2,417 \pm 105 a$ & $2,542 \pm 112 \mathrm{a}$ & 125 & 23.36 \\
\hline \multirow[t]{3}{*}{2010} & Pendleton, $\mathrm{OR}^{\mathrm{y}}$ & DM & Thiamethoxam & $3,697 \pm 328 \mathrm{a}$ & $3,768 \pm 335 \mathrm{a}$ & 71 & 13.87 \\
\hline & & DM & Thiamethoxam + abamectin & $3,697 \pm 328 \mathrm{a}$ & $3,701 \pm 339 a$ & 4 & 0.83 \\
\hline & & DM & Aldicarb & $3,697 \pm 328 \mathrm{a}$ & $4,219 \pm 315 b$ & 522 & 102.26 \\
\hline \multirow[t]{2}{*}{2011} & Four locations ${ }^{\mathrm{z}}$ & DMIT & Abamectin & $3,037 \pm 261 \mathrm{a}$ & $3,123 \pm 265 \mathrm{a}$ & 86 & 27.62 \\
\hline & & DMIT & Aldicarb & $3,037 \pm 261 \mathrm{a}$ & $3,835 \pm 180 b$ & 798 & 254.49 \\
\hline
\end{tabular}

u Mean \pm standard error of the mean. Comparative yield data followed by different letters within a row differed significantly at $\alpha=0.05$ as determined by Tukey's honestly significant difference test.

${ }^{v}$ Basic treatment was Dividend Extreme + Cruiser during 2009, Dividend Extreme during 2010, and Dividend Extreme + Rancona + Cruiser during 2011 (2011Dividend Rancona trials). Treatments in addition to the basic treatments included abamectin (Avicta) or thiamethoxam (Cruiser) applied to seed, or aldicarb (Temik) banded below the seed during 2010 or with the seed during 2011. Abbreviations: DMT $=$ difenoconazole + mefenoxam + thiamethoxam, $\mathrm{DM}=$ difenoconazole + mefenoxam, and DMIT $=$ difenoconazole + mefenoxam + ipconazole + thiamethoxam.

${ }^{\text {w }}$ Yield increase calculated as the difference between plots planted with additional seed or soil treatments compared with plots receiving the basic seed treatment.

${ }^{x}$ Farm-gate value of the additional yield produced by the additional treatment reflects the mean monthly farm-gate value for soft-white spring wheat in each state during the month immediately following that in which these crops were harvested; $\$ 186.91, \$ 196.09$ and $\$ 328.29 /$ metric tons in Oregon during 2009 , 2010 and 2011, respectively; and \$272.84 and \$328.29/metric tons in Idaho and Washington, respectively, during 2011.

${ }^{y}$ Means of four experiments at Pendleton, or two planting dates in each of two fields.

${ }^{\mathrm{z}}$ Means of experiments at four locations: St. Anthony, ID; Cove and Mission, OR; and Steptoe, WA. 
for additional value of the grain produced from these treatments was \$27.62/ha for abamectin and \$254.49 for aldicarb (Table 6).

Compared with untreated seed, none of the treatments led to an increase in grain test weight (data not presented). At Steptoe, the test weight was reduced by the aldicarb treatment compared with the fungicide-plus-insecticide control; 760 versus $779 \mathrm{~kg} / \mathrm{m}^{3}$, respectively $\left(\mathrm{HSD}_{0.05}=15\right)$.

Postharvest density of nematodes was not evaluated at Steptoe and did not differ among treatments at Mission or St. Anthony (Table 3). At Cove, the densities of $P$. neglectus and $H$. avenae were each strongly suppressed by aldicarb but not by abamectin, coinciding with observations of differences in grain yield among treatments.

2011 Proceed trials. Bayer CropScience products were evaluated in trials adjacent to the Syngenta Crop Protection trials on spring wheat at each of the four locations (Table 1). Stand establishment and grain test weight did not differ among treatments at any location (data not presented).

The root-knotting symptom was present on at least one root of every plant at each of the three locations where $H$. avenae was present (Table 4). Root knotting was severe and ratings did not differ among treatments at any location.

Grain yields differed among treatments only at Mission, where treatments of the high and low rates of B. firmus (Votivo) had greater yields $(4,721$ and $4,443 \mathrm{~kg} / \mathrm{ha}$, respectively) than those in the basic fungicide treatment (prothioconazole + tebuconazole + metalaxyl; Proceed Concentrate) plus spirotetramat, which had 3,530 $\mathrm{kg} / \mathrm{ha}\left(\mathrm{HSD}_{0.05}=528\right.$; Table 4$)$. However, as a group, grain yields for each of the three treatments in which spirotetramat (Movento) was applied were significantly $(P<0.01)$ lower than for the basic treatments to which spirotetramat had been added, suggesting a minor yield decline in response to the rate and timing of foliar applications of spirotetramat in that experiment. Grain yields did not differ among treatments at Steptoe, Cove, or St. Anthony (Table 4).

Postharvest densities of nematodes did not differ among treatments at the three locations sampled: Mission, Cove, and St. Anthony (Table 4). However, application of spirotetramat at St. Anthony compared with the appropriate control treatments resulted in a 52 to $71 \%$ decrease of postharvest density of $H$. avenae. One of the spirotetramat treatments at Cove also reduced the $H$. avenae density by $50 \%$ compared with the control treatment.

\section{Discussion}

Spring wheat was planted into five fields that were not cultivated between crops and two fields (Cove and St. Anthony, during 2011) that were cultivated immediately prior to being planted. Soil temperature at the time of planting was less than $10^{\circ} \mathrm{C}$ in five fields during 2010 and 2011. The spring-time weather during these years was characterized by frequent rains, between which plantings were made into cool, wet soils. It is likely that improved yields from seed treated with fungicides during 2009 and 2011, compared with untreated seed, resulted from the protective effects of fungicides against Pythium damping-off and root rot (20). The occurrence of Pythium damping-off was clearly apparent at Mission and Steptoe during 2011. At Mission, two replicates of the aldicarb treatment were abandoned after seedlings became well established but then died in plots where the aldicarb treatment coincided with a wind row of plant debris from the previous crop of canola. Plants died from damping-off caused by an undetermined species of Pythium. At Steptoe, in a spring wheat variety trial planted by another investigator into an adjacent field that had the same history as that for our experiment, the seedlings emerged uniformly but then most died in response to a heavy infection by a Pythium sp. The seed in the variety trial was planted into very wet soil 1 week before our trial was planted, and the seed had not been protected by a fungicide seed treatment. In our trial, seed treated with protectant fungicides and an insecticide produced a grain yield $473 \mathrm{~kg} / \mathrm{ha}$ greater than from wheat produced from untreated seed.

Our results at four locations during 2011 showed that spring wheat grown from seed treated with protectant fungicides nearly always resulted in greater productivity than when the seed had not been treated. Yield was increased by an average of $419 \mathrm{~kg} / \mathrm{ha}$, which was valued at $\$ 133.81 / \mathrm{ha}$. The cost of the seed treatment applied, propiconazole + mefenoxam + ipconazole + thiamethoxam (Dividend + Rancona + Cruiser), would have cost a grower $\$ 11.73 /$ ha. The net profit of the fungicide-plus-insecticide treatment would have averaged $\$ 122.08 /$ ha, due largely to protection of seed and seedlings from invasion by Pythium spp. in the cool, wet soils that were present when the trials were planted. These results underscored the continuing need to treat spring wheat seed with prophylactic fungicides in the PNW.

Abamectin slightly improved grain yield in two of six experiments: one field infested with $P$. thornei during 2009, none of the four fields infested with $P$. thornei during 2010, and in the only field infested primarily by $P$. neglectus but not $H$. avenae during 2011. Yield benefits achieved by treating wheat seed with abamectin do not appear to be sufficiently frequent or of great enough magnitude to warrant this use as a commercial practice in the PNW. A similar conclusion was reported for application of abamectin to corn seed planted into soil infested with Pratylenchus spp. in Nebraska (8). However, Oka et al. (19) reported that abamectin increased root length and reduced number of $H$. avenae in an inoculated study performed in small tubes $(50 \mathrm{ml})$ filled with sand and also in a study using naturally infested field soil in small pots $(700 \mathrm{ml})$. Numbers of new cysts were also reduced by about $50 \%$ (not statistically significant) by abamectin-treated seed planted into 10-liter buckets filled with naturally infested soil. Therefore, it may be possible to identify additional avermectin combinations or variants that could be evaluated in wheat fields infested by species of plant-parasitic nematodes.

By far the greatest impact of aldicarb in these studies occurred at Cove. Very large reductions in densities of both P. neglectus and $H$. avenae occurred in plots treated with aldicarb compared with plots treated with abamectin, likely explaining the extreme yield difference we observed between those treatments at that location. Aldicarb continues to be a desirable research tool in fields that are infested with nematodes but it is not registered and is not a candidate for commercial use on wheat, and was recently deregistered for use on all crops in the United States.

B. firmus applied at the low and high rates $\left(0.1 \times 10^{6}\right.$ and $10 \times$ $10^{6} \mathrm{CFU} / \mathrm{seed}$ ) slightly improved spring wheat yields compared with the control treatment in fields infested by either $P$. neglectus (at Mission) or $H$. avenae (at St. Anthony) but not in two fields that were infested with both of these species (at Cove and Steptoe). It is not known why yields were not also improved by an intermediate rate of $B$. firmus $\left(1 \times 10^{6} \mathrm{CFU} / \mathrm{seed}\right)$. In four unreported trials with winter wheat during 2011, at the same four locations as the spring wheat trials reported here, treatments identical to those in our 2011 Proceed series of experiments also failed to have an effect on stand density, grain yield, test weight, or root knotting caused by $H$. avenae. It was concluded that $B$. firmus as currently formulated was insufficiently reliable and of too little value to be recommended for commercial practice in wheat fields infested with plant-parasitic nematodes. A similar conclusion was reported for application of $B$. firmus to corn seed planted into soil infested with Pratylenchus spp. in Nebraska (8).

Spirotetramat reduced grain yield at the only site (Mission) where significant differences occurred among treatments. Although not statistically significant, spirotetramat provided numerically greater grain yield in each of three treatments in which it was tested at Steptoe but this was not observed at Cove or St. Anthony. Spirotetramat failed to reduce the postharvest density of $P$. neglectus, as was also observed in preliminary trials with $P$. thornei during 2010 (unpublished data). As in H. avenae-infested fields during 2010 (35), spirotetramat applications reduced the density of $H$. avenae by 50 to $71 \%$ in three of four comparisons evaluated at Cove and St. Anthony. Although this treatment may be helpful as a substitute for crop rotation to reduce the density of $H$. avenae, as suggested by Smiley et al. (35), it is unlikely to meet with commercial success due to variable effects on grain 
yield reported earlier (35) and confirmed during investigations reported here.

All nematicides except aldicarb were of variable or negligible value for suppressing damage by nematode species commonly encountered in PNW wheat fields. Our results indicated that these nematodes are unlikely to be controlled commercially by current formulations of abamectin, B. firmus, or spirotetramat. Future emphasis on management of plant-parasitic nematodes that affect wheat in the PNW should be placed on refining knowledge of effects of crop rotations $(33,34,36)$ and on developing tolerant and resistant genotypes that maintain adequate grain yield in infested soils and reduce nematode populations and, thereby, reduce the level of risk to subsequent plantings of intolerant cultivars and crops $(30,37,42,43)$.

\section{Acknowledgments}

Wheat seed was donated by Mid-Columbia Producers (Wasco, OR) and discounted nematode testing fees were provided by Western Laboratories (Parma, ID). Land and crop management assistance was provided by D. and B. Daw (St. Anthony, ID), S. and C. Johnson (Cove, OR), Confederated Tribes of the Umatilla Indian Reservation (Mission, OR), and J. and G. Scholz (Steptoe, WA). Field tours at experimental sites were coordinated by L. Ellis (University of Idaho), D. Walenta (Oregon State University), and S. Van Vleet (Washington State University). We thank the Idaho Wheat Commission, Oregon Wheat Commission, Washington Wheat Commission, Idaho Agricultural Experiment Station, Oregon Agricultural Experiment Station, United Stated Department of Agriculture-Agricultural Research Service Root Disease and Biological Control Unit (Pullman, WA), Bayer CropScience, and Syngenta Crop Protection for funding; and S. Goff, P. Thorgersen, N. Webster, S. Isbell, and H. Yan (Oregon State University) and C. Jackson and T. Shelman (University of Idaho) for technical assistance.

\section{Literature Cited}

1. Cabrera, J. A., Kiewnick, S., Grimm, C., Dababat, A. E. A., and Sikora, R. A. 2009. Effective concentration and range of activity of abamectin as seed treatment against root-knot nematodes of tomato under glasshouse conditions. Nematology 11:909-915.

2. Dybas, R. A. 1989. Avermectin use in crop protection. Pages 287-310 in: Ivermectin and Abamectin. W. C. Campbell, ed. Springer-Verlag. New York.

3. Faske, T. R., and Starr, J. L. 2006. Sensitivity of Meloidogyne incognita and Rotylenchus reniformis to abamectin. J. Nematol. 38:240-244.

4. Faske, T. R., and Starr, J. L. 2007. Cotton root protection from plant-parasitic nematodes by abamectin-treated seed. J. Nematol. 39:27-30.

5. Giannakou, I. O., Karpouzas, D. G., and Prophetou-Athanasiadou, D. 2004. A novel non-chemical nematicide for the control of root-knot nematode. Appl. Soil Ecol. 26:69-79.

6. Hafez, S. I., Golden, A. M., Rashid, R., and Handoo, Z. 1992. Plant-parasitic nematodes associated with crops in Idaho and eastern Oregon. Nematropica 22:193-204.

7. Hamida, A. O., El-Gindi, A. Y., Hoda, H. A., Youssef, M. M., and Asmahan, M. L. 2006. Evaluation of the nematicidal effects of a biotechnological product (abamectin) on Meloidogyne incognita, root-knot nematode infecting cowpea plants. Pakistan J. Nematol. 24:75-79.

8. Jackson, T. A., and Behn, J. L. 2010. Evaluation of VOTIVO biological seed treatment nematicide on lesion nematodes of corn in Nebraska. Plant Dis. Manage. Rep. 4:N033.

9. Keren-Zur, M., Antonov, J., Bercovitz, A., Feldman, K, Husid, A., Kenan, G., Markov, N., and Rebhun, M. 2000. Bacillus firmus formulations for the safe control of root-knot nematodes. Proc. Brighton Crop Prot. Conf. Pests Dis. 2A:47-52.

10. Lawrence, K. S., and Hatchett, T. B. 2007. Evaluation of Avicta variants for root-knot nematode management in cotton in central Alabama. Plant Dis. Manage. Rep. 1:N012.

11. Lawrence, K. S., Hatchett, T. B., Gazaway, W. S., Lawrence, G. W., and Akridge, R. 2007. Evaluation of Avicta variants for reniform nematode management in cotton in south Alabama. Plant Dis. Manage. Rep. 1:N011.

12. Lawrence, K. S., Moore, S. R., Castillo, J. D., Sekora, N., Lawrence, G. W., and Akridge, R. 2009. Evaluation of Aeris, Abermectin and Temik for reniform nematode management in south Alabama. Plant Dis. Manage. Rep. 3:FC081

13. McKenry, M., Buzo, T., and Kaku, S. 2010. Performance of spirotetramat foliar on Pratylenchus vulnus infected Juglans spp. (Abstr.) J. Nematol. 42:257.

14. McKenry, M., Kaku, S., and Buzo, T. 2009. Evaluation of Movento (spirotetramat) for efficacy against nematodes infesting perennial crops. (Abstr.) J. Nematol. 41:355.

15. Nauen, R., Reckmann, U., Thomzik, J., and Thielert, W. 2008. Biological profile of spirotetramat (Movento) - a new two-way systemic (ambimobile) insecticide against sucking pest species. Bayer CropSci. J. 61:245-278.

16. Mendoza, A. R., Kiewnick, S., and Sikora, R. A. 2008. In vitro activity of
Bacillus firmus against the burrowing nematode Radopholus similis, the root-knot nematode Meloidogyne incognita and the stem nematode Ditylenchus dipsaci. Biocontrol Sci. Technol. 18:377-389.

17. Montfort, W. S., Kirkpatrick, T. L., Long, D. L., and Rideout, S. 2006. Efficacy of a novel nematicidal seed treatment against Meloidogyne incognita in cotton. J. Nematol. 38:245-249.

18. Ogg, A. G., Jr., Smiley, R. W., Pike, K. S., McCaffrey, J. P., Thill, D. C., and Quisenberry, S. S. 1999. Integrated pest management for conservation systems. Pages 97-128 in: Advances in Conservation Farming. E. L. Michalson, R. I. Papendick, and J. E. Carlson, eds. CRC Press, Boca Raton, LA

19. Oka, Y., Gözel, U., Spiegel, Y., and Mor, M. 2009. Cereal cyst nematodes in Israel, and their biology and control strategies. Pages 118-122 in: Cereal Cyst Nematodes: Status, Research and Outlook. I. T. Riley, J. M. Nicol, and A. A. Dababat, eds. CIMMYT, Ankara, Turkey.

20. Paulitz, T., Smiley, R., and Cook, R. J. 2002. Insights into the prevalence and management of soilborne cereal pathogens under direct seeding in the Pacific Northwest U.S.A. Can. J. Plant Pathol. 24:416-428.

21. Phipps, P. M., Hu, J., and Eisenback, J. D. 2009. Comparison of seed treatments to Temik $15 \mathrm{G}$ in-furrow for control of southern root-knot nematode. Plant Dis. Manage. Rep. 3:N034.

22. Proctor, J. R., and Marks, C. F. 1974. The determination of normalising transformations for nematode count data from soil samples and of efficient sampling schemes. Nematologica 20:395-406.

23. Putter, I., MacConnell, J. G., Prieser, F. A., Haidri, A. A., Ristich, S. S., and Dybas, R. A. 1981. Avermectins: novel insecticides, acaricides and nematicides from a soil microorganism. Experimentia 37:963-964.

24. Rich, J. R., and Wright, D. L. 2008. Efficacy of Temik, Avicta and Aeris, applied alone and in combination, for management of reniform nematodes on cotton in north Florida. Plant Dis. Manage. Rep. 2:N040.

25. Safferling, M., ed. 2008. Spirotetramat: the first phloem-mobile and fully systemic insecticide. Bayer CropSci. J. 61(2).

26. Sasser, J. N., Kirkpatrick, T. L., and Dybas, R. A. 1982. Efficacy of Avermectins for root-knot control in tobacco. Plant Dis. 66:691-693.

27. Seyb, A., and Westphal, A. 2008. Seed and planting treatments for managing soybean cyst nematode and sudden death syndrome in soybean in North-central Indiana. Plant Dis. Manage. Rep. 2:ST001.

28. Shoop, W., Mrozik, H., and Fisher, M. H. 1995. Structure and activity of avermectins and milbemycins in animal health. Vet. Parasitol. 59:139-156.

29. Smiley, R. W. 2009. Occurrence, distribution and control of Heterodera avenae and $H$. filipjevi in the western USA. Pages 35-40 in: Cereal Cyst Nematodes: Status, Research and Outlook. I. T. Riley, J. M. Nicol, and A. A. Dababat, eds. CIMMYT, Ankara, Turkey.

30. Smiley, R. W. 2010. Root-lesion nematodes: biology and management in Pacific Northwest wheat cropping systems. PNW Ext. Bul. 617, Oregon State University, Corvallis.

31. Smiley, R. W. 2010. Root-lesion nematodes reduce yield of intolerant wheat and barley. Agron. J. 101:1322-1335.

32. Smiley, R. W., Backhouse, D., Lucas, P., and Paulitz, T. 2009. Diseases which challenge global wheat production-root, crown, and culm rots. Pages 125-153 in: Wheat Science and Trade. B. F. Carver, ed. Wiley-Blackwell, Ames, IA.

33. Smiley, R. W., Ingham, R. E., Uddin, W., and Cook, G. H. 1994. Crop sequences for managing cereal cyst nematode and fungal populations of winter wheat. Plant Dis. 78:1142-1149.

34. Smiley, R. W., and Machado, S. 2009. Pratylenchus neglectus reduces yield of winter wheat in dryland cropping systems. Plant Dis. 93:263-271.

35. Smiley, R. W., Marshall, J. M., and Yan, G. P. 2011. Effect of foliarly-applied spirotetramat on reproduction of Heterodera avenae on wheat roots. Plant Dis. 95:983-989.

36. Smiley, R. W., Merrifield, K., Patterson, L.-M., Whittaker, R. G., Gourlie, J. A., and Easley, S. A. 2004. Nematodes in dryland field crops in the semiarid Pacific Northwest USA. J. Nematol. 36:54-68.

37. Smiley, R. W., and Nicol, J. M. 2009. Nematodes which challenge global wheat production. Pages 171-187 in: Wheat Science and Trade. B. F. Carver, ed. Wiley-Blackwell, Ames, IA.

38. Smiley, R. W., Whittaker, R. G., Gourlie, J. A., and Easley, S. A. 2005 Pratylenchus thornei associated with reduced wheat yield in Oregon. J. Nematol. 37:45-54

39. Smiley, R. W., Whittaker, R. G., Gourlie, J. A., and Easley, S. A. 2005 Suppression of wheat growth and yield by Pratylenchus neglectus in the $\mathrm{Pa}$ cific Northwest. Plant Dis. 89:958-968.

40. Smiley, R. W., Whittaker, R. G., Gourlie, J. A., and Easley, S. A. 2006. Geocenamus brevidens associated with reduced yield of no-till annual spring wheat in Oregon. Plant Dis. 90:885-890.

41. Smiley, R. W., Whittaker, R. G., Gourlie, J. A., Easley, S. A., and Ingham, R. E. 2005. Plant-parasitic nematodes associated with reduced wheat yield in Oregon: Heterodera avenae. J. Nematol. 37:297-307.

42. Smiley, R. W., and Yan, G. P. 2010. Cereal cyst nematodes: biology and management in Pacific Northwest wheat, barley and oat crops. PNW Ext. Bull. 620, Oregon State University, Corvallis.

43. Smiley, R. W., Yan, G. P., and Pinkerton, J. N. 2011. Resistance of wheat, barley and oat to Heterodera avenae in the Pacific Northwest USA Nematology 12:539-552.

44. Strausbaugh, C. A., Bradley, C. A., Koehn, A. C., and Forster, R. L. 2004. 
Survey of root diseases of wheat and barley in southeastern Idaho. Can. J. Plant Pathol. 26:167-176.

45. Tian, B., Yang, J., and Zhang, K. 2007. Bacteria used in the biological control of plant-parasitic nematodes: populations, mechanisms of action, and future prospects. FEMS Microb. Ecol. 61:197-213.

46. Vermeer, R., and Baur, P. 2008. Movento Product development: custommade formulations for an exceptional active ingredient. Bayer CropSci. J. 61:141-158.

47. USDA-NASS, United States Department of Agriculture National Agricultural Statistics Service. 2011. http://www.nass.usda.gov

48. USDA-NRCS, United States Department of Agriculture Natural Resources Conservation Service Web Soil Survey. 2011. http://websoilsurvey.nrcs. usda.gov/app/WebSoilSurvey.aspx
49. Wislocki, P. G., Grosso, L. S., and Dybas, R. A. 1989. Environmental aspects of abamectin use in crop protection. Pages 182-200 in: Ivermectin and Abamectin. C. W. Campbell, ed. Springer-Verlag, New York.

50. Yan, G. P., and Smiley, R. W. 2010. Distinguishing Heterodera filipjevi and $H$. avenae using polymerase chain reaction-restriction fragment length polymorphism and cyst morphology. Phytopathology 100:216-224.

51. Yan, G. P., Smiley, R. W., and Okubara, P. A. 2012. Detection and quantification of Pratylenchus thornei in DNA extracted from soil using real-time PCR. Phytopathology 102:14-22.

52. Yan, G. P., Smiley, R. W., Okubara, P. A., Skantar, A., Easley, S. A., Sheedy, J. G., and Thompson, A. L. 2008. Detection and discrimination of Pratylenchus neglectus and $P$. thornei in DNA extracts from soil. Plant Dis. 92:1480-1487. 